\title{
Growing and Sustaining Black Teachers: Examining Contemporary Research in the Field
}

\author{
Conra D. Gist ${ }^{1}$
}

Published online: 2 March 2018

(C) Springer Science+Business Media, LLC, part of Springer Nature 2018

Michele Foster wrote her seminal work Black Teachers on Teaching a little over 20 years ago. When I read her book in a History of Education class it was the first time program coursework in my Masters and Doctoral studies linked my experiences as a Black teacher with the historical legacy of others who came before me. In the book foreword, Lisa Delpit articulates the value of the work to the education field, keenly forecasting many of the challenges Black teachers currently face. The problem of finding professional spaces Black educators can experience autonomy and freedom to define their professional visions remains a challenge 20 years later (Albert Shanker Institute 2015). The presence of hiring and evaluation practices that devalue or overlook the pedagogical potential and prowess Black educators bring to the profession continues to be a barrier (Bailey et al. 2016; D'Amico et al. 2017; White 2016). And while it is clear Black teachers can make a difference for all students (Cherng and Halpin 2016), the realities of Black education and lives in America reaffirm the weighty role Black teachers are frequently positioned to play for Black students. The unequal and inequitable educational experiences of Black students, typically placed in poorly resourced schools in disrepair, and devoid of access to rigorous upper level course offerings taught by experienced and proven teachers, provides a window through which to see current challenges in the system (U.S. Commission of Human Rights 2018). The \#BlackLivesMatter Week of Action in Schools the second week of February 2018 brought attention to these issues, elevating the need for action across a plethora of quality of life domains for Black people in America.

And although Black educators currently represent $6.7 \%$ of the educator workforce (Taie and Goldring 2017), their impact on Black students can mean the difference between having access to gifted and talented programs or being denied (Grissom

Conra D. Gist

gist@uark.edu

1 University of Arkansas, Peabody Hall 203, Fayetteville, AR 72701, USA 
and Redding 2016); being likely to graduate or dropping out from high school (Gershenson et al. 2017); receiving positive affirming appraisal of academic abilities or being overlooked (Irvine 2003); or being routed toward the school to prison pipeline or remaining in safe and caring classroom spaces (Evans-Winters 2011; Morris 2016). Given the continued limited growth of the Black teacher pool, coupled with the burgeoning body of research supporting their positive difference making impact on students, there is a need for original scholarship that does not simply synthesize current research on Black teachers, but rather, shines light on various ways to grow and sustain a cadre of Black teachers along their educational and professional trajectories in the twenty-first century. In the same way that Black teachers were systematically disenfranchised to dwindle in numbers (Foster 1997), supports can be systematically created to increase their number and representation. Toward this end, this Special Issue features research efforts that illuminate approaches for fortifying and building the Black teacher workforce in the United States.

Most research on Black teachers primarily studies their experiences as a monolithic group and examines a single phase of teacher development (i.e., recruitment, preparation, induction, or tenure), stopping short of taking up longitudinal and integrated queries of their teaching and learning trajectory over time. In the article "Black Educators Fight Back: Facing and Navigating Vulnerability and Stress in Teacher Development", I examine Black educators' experiences in Grow Your Own (GYO) programs at the intersection of social and human development constructs and frameworks to understand how they move along the teacher development continuum from teacher candidates to classroom teachers. There is also a need to better understand the diverse and fluid gendered positionalities Black teachers assume in our nation's schools. Travis Bristol and Marcelle Mentor, in the article "Policing and Teaching: The Positioning of Black Male Teachers as Agents in the Universal Carceral Apparatus", describe a research study on how Black male teachers perceived that their peers and school administrators positioned them to serve primarily as disciplinarians first and teachers second. In contrast, examining the experiences of Black female educators' initial draw to urban schools, Abiola Farinde-Wu, in the article "\#Blackwomenatwork: Teaching and Retention in Urban Schools", reframes the implicit biases often surrounding urban schools and Black women's decisions to teach in these settings.

Further, it is becoming more pertinent to identify concrete models and professional development structures that support and sustain Black educators. As such, Chukwunyere Okezie, in the article "The Marygrove College Griot Program: A Grow Your Own Program for African American Male Teachers", provides an overview of a pipeline program in Detroit, The Griot Model, committed to increasing the number of Black males entering the profession. However, once Black teachers participate in programs that facilitate their entry to the profession, sustaining their presence in the profession is vital (Albert Shanker Institute 2015). Micia Mosely provides possible professional development interventions to address the early exit of Black teachers via racial affinity professional development, in the article "The Black Teacher Project: How Racial Affinity Professional Development Sustains Black Teachers". This work also highlights the need for education researchers who have commitments to interrogate race and racism in 
education to explore their function and form within particular disciplines. Monica Ridgeway and Ebony McGee emphasize such efforts in the article "Black Mathematics Educators: Researching toward Racial Emancipation of Black Students", which presents findings from a metasynthesis literature review that Black mathematics education researchers strategically disrupt the deficit narrative about Black students and often select theoretical frameworks that allow them to focus on race and how racism operates in mathematics education. The disruptive nature of work that counters scholarship that normalizes deficit and marginal performance in Black education is critical because it casts Black students in a new light, revealing possibilities and evidence of Black academic excellence.

The multiple ways in which Black education and teachers are characterized in public discourse to assert their potential and utility becomes apparent in the article, "Understanding the Black Teacher through Metaphor" by Anthony Brown, Mary Dilworth, and Keffrelyn Brown. This article deconstructs the metaphoric meaning of the Black teacher through four key metaphors, making sense of how they take shape within historically situated contexts and continue to endure over time. The framing of Black teachers in educational discourse also has implications for policy at multiple levels of educator preparation. Thus, the final piece, "Winter is Coming: Forecasting the Impact of edTPA on Black Teachers and Teachers of Color" by Emery Petchauer, Anica Bowe, and Julene Wilson, traces how high-stakes teacher exams have shaped the career entry opportunities for Black teachers and makes recommendations for understanding and mobilizing against the emerging era of high-stakes performance exams brought about by the edTPA.

There are twenty narratives in Black Teachers on Teaching. Six elders, twelve veterans, and two novices. At the close of Michele Foster's introduction to this groundbreaking book she notes:

The shrinking numbers of black teachers have compelled me to publish numbers these contemporary accounts of black teachers. In the pages that follow, teachers talk about the racism in segregated and desegregated schools, the repeated cycles of attempted and aborted reform efforts, and the different perceptions of black and white teachers about the ability and need of black students, parents, and communities. Much of what these teachers say is controversial. Nonetheless, it is my hope that these accounts will provide a voice for an historically marginalized group, that in the process they will enhance our capacity to understand the experiences of black teachers, and they will assist contemporary and future African-Americanists, historians, and sociologists in reaching a more complete understanding of education, schooling, teaching, and learning in the United States. (LI).

Published in 1997, I take the still ever pressing relevance of these introductory comments some 20 years ago, to signify the work yet still needed to not only continue advancing the justice efforts of Black teachers, but break new ground in such efforts. Our scholarship must script a different set of bold, innovative, and unrestrained research studies about the status of Black teachers if we want a new story to be told amount the representation of Black educators in this country 
20 years from now (Gist 2017). We will have to seek new methodologies, while fusing wisdom and lessons from Black teacher development that have worked in the past (Loder-Jackson 2012; Walker 2009), to forge impactful research that sets the content, character and tempo of policies, practices, and pedagogies for the academic and professional advancement of Black teachers. And so, it is my hope, similar to the sentiment expressed by Foster (1997) in her closing introductory paragraph, that this Special Issue expand understanding, plant seeds of possibilities, and inspire reform agendas committed to growing and sustaining Black educators in the twenty-first century.

\section{References}

Albert Shanker Institute. (2015). The state of teacher diversity in American education. Retrieved December 1, 2015 from http://www.shankerinstitute.org/sites/shanker/files/The\%20State\%20Teacher\%20 Diversity\%20Exec\%20Summary_0.pdf.

Bailey, J., Bocala, C., Shakman, K., \& Zweig, J. (2016). Teacher demographics and evaluation: A descriptive study in a large urban district. Retrieved May 2, 2017 from https://ies.ed.gov/ncee/edlabs/ regions/northeast/pdf/REL_2017189.pdf.

Cherng, H. Y. S., \& Halpin, P. F. (2016). The importance of minority teachers: Student perceptions of minority versus White teachers. Educational Researcher, 45(7), 407-420.

D’Amico, D., Pawlewicz, R. J., Earley, P. M., \& McGeehan, A. P. (2017). Where are all the Black teachers? Discrimination in the teacher labor market. Harvard Educational Review, 87(1), 26-49.

Evans-Winters, V. E. (2011). Teaching black girls: Resiliency in urban classrooms (2nd ed.). New York: Peter Lang.

Foster, M. (1997). Black teachers on teaching. New York: The New Press.

Gershenson, S., Hart, C., Lindsay, C., \& Papageorge, N. W. (2017). The long-run impacts of same-race teachers. Retrieved from: https://www.econstor.eu/bitstream/10419/161253/1/dp10630.pdf.

Gist, C. D. (2017). The epistemological work of Black teachers: Tilling the fertile soil of intellectual activism. In R. Brock, D. Nix-Stevenson, \& P. Chamness Miller-Kuriyama (Eds.), Critical black studies reader (pp. 231-241). New York: Peter Lang.

Grissom, J. A., \& Redding, C. (2016). Discretion and disproportionality: Explaining the underrepresentation of high-achieving students of color in gifted programs. AERA Open, 2(1), 1-25.

Irvine, J. J. (2003). Educating teachers for diversity: Seeing with a cultural eye. New York: Teachers College Press.

Loder-Jackson, T. L. (2012). Hope and despair: Southern Black women educators across pre- and postcivil rights cohorts theorize about their activism. Educational Studies, 48(3), 266-295.

Morris, M. W. (2016). Pushout: The criminalization of Black girls in schools. New York: The New Press.

Taie, S., \& Goldring, R. (2017). Characteristics of public elementary and secondary school teachers in the United States: Results from the 2015-16 national teacher and principal survey first look (NCES 2017-072). Washington, DC: National Center for Education Statistics. Retrieved November 15, 2017 from https://nces.ed.gov/pubs2017/2017072.pdf.

U.S. Commission on Civil Rights. (2018). Public education funding inequity in an era of increasing concentration of poverty and resegregation. Retrieved February 20, 2018 from http://www.usccr.gov/ pubs/2018-01-10-Education-Inequity.pdf.

Walker, V. S. (2009). Hello professor: A Black principal and professional leadership in the segregated South. Chapel, NC: University of North Carolina Press.

White, T. (2016). Teach for America's paradoxical diversity initiative: Race, policy, and Black teacher displacement in urban public schools. Education Policy Analysis, 24(16), 1-37. 